\title{
Evidence-Based Review of the Management of Hepatic Hydrothorax
}

\author{
Amita Singh Abubakr Bajwa Adil Shujaat \\ Department of Pulmonary and Critical Care, UF College of Medicine at Jacksonville, Jacksonville, Fla., USA
}

\section{Key Words}

Hepatic hydrothorax - Nonmalignant pleural effusion .

Pleurodesis - Transjugular intrahepatic portosystemic shunt

\begin{abstract}
Hepatic hydrothorax $(\mathrm{HH})$ is an example of a porous diaphragm syndrome. Portal hypertension results in the formation of ascitic fluid which moves across defects in the diaphragm and accumulates in the pleural space. Consequently, the treatment approach to $\mathrm{HH}$ consists of measures to reduce the formation of ascitic fluid, prevent the movement of ascitic fluid across the diaphragm, and drain or obliterate the pleural space. Approximately $21-26 \%$ of cases of $\mathrm{HH}$ are refractory to salt and fluid restriction and diuretics and warrant consideration of additional treatment measures. Ideally, liver transplantation is the best treatment option; however, most of the patients are not candidates and most of those who are eligible die while waiting for a transplant. Treatment measures other than liver transplantation may not only provide relief from dyspnea but also improve patient survival and serve as a bridge to liver transplantation.
\end{abstract}

Copyright $\odot 2013$ S. Karger AG, Basel

\section{KARGER}

(c) 2013 S. Karger AG, Basel

0025-7931/13/0862-0155\$38.00/0

E-Mail karger@karger.com

www.karger.com/res

\section{Introduction}

Hepatic hydrothorax $(\mathrm{HH})$ is defined as transudative pleural effusion associated with portal hypertension without any cardiac, pulmonary and pleural disease. The presence of portal hypertension but not end-stage liver disease is a requirement for the development of $\mathrm{HH}$ [1]. The amount of pleural fluid is usually greater than $500 \mathrm{ml}$. HH is not a common complication of end-stage liver disease. A large amount of ascitic fluid can be easily tolerated by patients but even 1-2 liters of pleural fluid can produce significant symptoms of dyspnea due to reduced capacitance of the thoracic cavity as compared to the abdominal cavity. Therefore, the management of $\mathrm{HH}$ becomes challenging in patients with portal hypertension. Different treatment options for $\mathrm{HH}$ including medical management with diuretics, thoracentesis, and pleurodesis with or without repair of diaphragmatic defects have been proposed in the literature. The aim of the present review is to discuss the pathophysiology, clinical manifestations and diagnosis of this disorder and to present an evidencebased review of the management of $\mathrm{HH}$. The search engines that were used to obtain data were PubMed and Google Scholar (table 1) including case reports, original studies and a meta-analysis in English language only. 
Table 1. Search engines used for literature review

\begin{tabular}{ll}
\hline $\begin{array}{l}\text { Search } \\
\text { engine }\end{array}$ & PubMed, Google Scholar \\
\hline $\begin{array}{l}\text { Search } \\
\text { words }\end{array}$ & $\begin{array}{l}\text { hepatic hydrothorax, transudative pleural effusion, } \\
\text { non-malignant pleural effusion, thoracentesis, } \\
\text { pleurodesis, thoracoscopy, transjugular intrahepatic } \\
\text { portosystemic shunt (TIPS), liver transplant, } \\
\text { spontaneous bacterial empyema (SBEM) }\end{array}$ \\
\hline
\end{tabular}

\section{Incidence}

The incidence of $\mathrm{HH}$ varies depending on the method of detecting pleural fluid. The incidence has been reported to be $4-6 \%$ in studies that used chest X-ray to diagnose pleural effusion [2-6]. However, in a series of 862 cirrhotic patients from China that used ultrasonography to detect pleural effusion, the incidence was found to be $15 \%$ [7]. $\mathrm{HH}$ accounts for $2-3 \%$ of all pleural effusions $[8,9]$. Pleural effusions in cirrhotic patients are predominantly right sided accounting for about $79.5 \%$ of all effusions as compared to pleural effusions of cardiac origin which are typically bilateral. However, $17.5 \%$ of effusions can be left sided and $3 \%$ can be bilateral [10]. The incidence of spontaneous bacterial empyema (SBEM), which is defined as infection of $\mathrm{HH}$ after exclusion of pneumonia, has been similar to the incidence of spontaneous bacterial peritonitis (SBP). In a prospective study, the incidence of SBEM was found to be $13 \%$ [11], similar to the $15-20 \%$ incidence of SBP in hospitalized patients with cirrhosis [12, 13]. Interestingly, up to $40 \%$ of SBEM patients are not associated with SBP [11].

\section{Pathophysiology}

The underlying mechanisms for $\mathrm{HH}$ are similar to those leading to fluid accumulation and ascites in portal hypertension. Portal hypertension and splanchic vasodilation plays an important role in the formation of ascites. Several mechanisms have been postulated for the development of HH in patients with liver cirrhosis. These include the transfer of the peritoneal fluid into the pleural space via diaphragmatic defects [14], hypoalbuminemia resulting in decreased colloid osmotic pressure [15] and lymphatic leakage from the thoracic duct [16]. The direct passage of fluid from the peritoneal to the pleural cavity through diaphragmatic defects has been proposed as the most accepted mechanism explaining most cases of $\mathrm{HH}$.
This has been observed in many studies [17-19]. This mechanism was first suggested by Lieberman et al. [20] following the observation of a pneumothorax after injection of air into the peritoneal cavity. When air is infused intraperitoneally in patients with $\mathrm{HH}$, it can be seen on the chest X-ray performed $48 \mathrm{~h}$ later as lucency above the right side of the diaphragm. Other studies have also suggested the rapid movement of air, dyes or radiolabeled material from the peritoneal cavity into the pleural space as the mechanism for $\mathrm{HH}$ [21].

Huang et al. [22] classified the diaphragmatic defects thoracoscopically into four morphological types:

- Type 1: no obvious defect

- Type 2: blebs lying in the diaphragm

- Type 3: broken defects (fenestrations) in the diaphragm

- Type 4: multiple gaps in the diaphragm

The microscopic examination of these defects reveals discontinuities in the collagen bundles of the tendinous portion of the diaphragm [20]. Most of these defects occur on the right side because of the close anatomical proximity of the liver with the diaphragm. The negative intrathoracic pressure and the close proximity of the liver with diaphragm, which acts a piston, cause the unidirectional movement of fluid from the abdominal to the pleural cavity. This unidirectional valvular mechanism of development of $\mathrm{HH}$ has been confirmed with various studies using nuclear imaging with ${ }^{99 \mathrm{~m}} \mathrm{Tc}$-human albumin or ${ }^{99 \mathrm{~m}} \mathrm{Tc}$ sulfur colloid or dye. These studies have demonstrated the passage of these radioisotopes from the abdominal to the pleural cavity in the first $24 \mathrm{~h}$ after administration $[23,24]$. Even though the diaphragmatic defects can be seen in $20 \%$ of noncirrhotic patients, pneumothorax rarely develops after laparoscopic procedures [25]. This is because the pressure gradient between the peritoneal and the pleural cavity is altered in patients with ascites; the increased intra-abdominal pressure and diaphragmatic thinning due to malnutrition in cirrhotic patients leads to enlargement of these defects with subsequent unidirectional passage of ascitic fluid into the chest. Herniation of the peritoneum into the pleural space can develop because of the increase in gaps between the muscle fibers of the diaphragm with increased intra-abdominal pressure. These herniations are known as pleuroperitoneal blebs which may rupture, facilitating the fluid passage. In patients without ascites, the mechanism of $\mathrm{HH}$ formation is similar. In these patients, virtually all ascitic fluid rapidly crosses the diaphragm into the pleural space. Ascites develops in these patients when the formation of ascitic fluid exceeds the lymphatic absorption and transfer into the pleural space. 
SBEM occurs due to the direct spread of infection from the peritoneal space through diaphragmatic defects. However, SBEM has also been reported in patients without ascites, supporting the hypothesis that hematogenous spread of enteral microorganisms to the pleural space is also responsible for the development of SBEM $[11,26]$. Enterobacteriaceae (Escherichia coli and Klebsiella pneumoniae), streptococcus species and enterococcus species are the most frequent flora seen in SBEM.

\section{Clinical Presentation}

The clinical presentation is usually dominated by signs and symptoms of cirrhosis and portal hypertension, i.e. ascites, spider naevi, asterixis, hepatosplenomegaly, caput medusa and hepatic encephalopathy. Most of the effusions are right sided but a few patients can present with left-sided or bilateral effusions [10]. Patients may be asymptomatic in whom pleural effusion can be an incidental finding on chest imaging performed for other reasons [27] or they may have pulmonary symptoms of shortness of breath, cough, hypoxemia or respiratory failure associated with large pleural effusions. These clinical features depend on various factors like the volume of the pleural fluid, the rapidity of accumulation of the pleural fluid and the presence of associated cardiopulmonary disease. In a review of 24 cases in a 1-year period, most of the effusions were small to moderate in size, and only $6 \%$ had large effusions occupying more than half a hemithorax [28]. Sometimes cirrhotic patients present primarily with pulmonary complaints related to hydrothorax [29-32]. Isolated hydrothorax without any clinical ascites has been reported in about $20 \%$ of patients [33], but when both computed tomography (CT) and ultrasonography were used, it was found in $7 \%$ of the patients [34].

A case of acute tension hydrothorax leading to respiratory failure due to sudden rupture of a large pleuroperitoneal bleb secondary to increased intra-abdominal pressure was also reported [35]. Large effusions have the potential of causing cardiac tamponade with profound systemic hypotension that may require immediate intervention [36]. SBEM should always be suspected when patients develop fever, pleuritic chest pain or encephalopathy.

\section{Diagnosis}

$\mathrm{HH}$ is confirmed in a patient with portal hypertension and ascites who present with pleural effusion after excluding any primary pulmonary, cardiac or pleural dis- ease. Effusions can be seen on chest X-ray or on other imaging studies like ultrasonography and CT of the chest or abdomen.

The initial evaluation of effusion should be the analysis of pleural fluid to identify the nature of the fluid and to rule out any other causes of effusions like infections, including SBEM, inflammation or malignancy. In a study of 60 cirrhotic patients with pleural effusions [37], 42 patients $(70 \%)$ were found to have pleural fluid analysis compatible with hydrothorax. The remaining 18 patients (30\%) had a diagnosis other than HH like SBEM in 9 (15\%), tuberculosis in 2, adenocarcinoma in 2 and parapneumonic empyema in 2 patients; 3 were undiagnosed exudates. Also, $64 \%$ of the left-sided effusions were found to be complicated compared with $20 \%$ right-sided complicated effusions. Hence, thoracentesis with analysis of pleural fluid is a must in cirrhotic patients with pleural effusions. Also, left-sided pleural effusions should not be assumed to be uncomplicated $\mathrm{HH}$, as also shown in previous studies [38]. Pleural fluid analysis should include protein, albumin and lactate dehydrogenase (LDH) levels, cell count, gram stain and culture examination. $\mathrm{HH}$ is transudative in nature. In a retrospective study of $41 \mathrm{HH}$ patients, solitary $\mathrm{HH}$ was found in 33 patients [34]. Of these 33 patients, 31 (94\%) were transudates. Sixteen (48\%) had a total protein level $<1.5 \mathrm{~g} / \mathrm{dl}$ in the pleural fluid, none had a serum albumin value $<1.5 \mathrm{~g} / \mathrm{dl}$, microbiologic cultures were negative in 31 patients, and in 30 patients, cytology was negative for any malignant cells. The median pleural fluid $\mathrm{pH}$ was 7.49 , total protein was $1.5 \mathrm{~g} / \mathrm{dl}$ and LDH was $65 \mathrm{IU} / \mathrm{l}$. The median pleural fluid/ serum protein ratio and median pleural fluid $\mathrm{LDH}$ /upper limit of normal LDH ratio were 0.25 and 0.27 , respectively. The absolute neutrophil count (ANC) was $<250 / \mu l$. Only a single patient had a protein discordant exudate despite $83 \%$ of patients receiving diuretics. Authors concluded that diuretic therapy has a minimal effect in changing the pleural fluid chemistry in HH. However, when $\mathrm{HH}$ is an exudate probably because of diuretics, the serum/pleural fluid albumin ratio should be calculated, and a value $<0.6$ is classified as transudate [39]. The characteristics of the pleural fluid in $\mathrm{HH}$ are listed in table 2. As in transudative pleural effusion, total protein is $<2.5 \mathrm{~g} / \mathrm{dl}$ [40] in $\mathrm{HH}$ with low $\mathrm{LDH}$ and glucose levels similar to the serum glucose level [9]. The serum/pleural fluid albumin gradient is usually $>1.1 \mathrm{~g} / \mathrm{dl}$, similar to that of ascites resulting from portal hypertension, although this has not been studied extensively.

Other tests that should be considered with respect to the pleural fluid include $\mathrm{pH}$, triglycerides, adenosine de- 
Table 2. Characteristics of pleural fluid in $\mathrm{HH}$

Polymorphonuclear count $<250$ cells $/ \mathrm{mm}^{3}$

Total protein $<2.5 \mathrm{~g} / \mathrm{dl}$

Pleural fluid total protein/serum total protein ratio $<0.5$

Pleural fluid $\mathrm{LDH} /$ serum $\mathrm{LDH}<0.6$

Serum pleural to fluid albumin gradient $>1.1 \mathrm{~g} / \mathrm{dl}$

Glucose level similar to that of serum

$\mathrm{pH} 7.4-7.55$

Table 3a. CTP scoring

\begin{tabular}{|c|c|}
\hline $\begin{array}{l}\text { Encepha- } \\
\text { lopathy }\end{array}$ & $\begin{array}{l}\text { None } \\
\text { Grade 1: altered mood or confusion ( } 2 \text { points) } \\
\text { Grade 2: inappropriate behavior, impending } \\
\text { stupor, somnolence ( } 2 \text { points) } \\
\text { Grade 3: markedly confused, stuporous but } \\
\text { arousable ( } 3 \text { points) } \\
\text { Grade 4: comatose/unresponsive (3 points) }\end{array}$ \\
\hline Ascites & $\begin{array}{l}\text { Absent ( } 1 \text { point }) \\
\text { Slight }(2 \text { points }) \\
\text { Moderate ( } 3 \text { points })\end{array}$ \\
\hline Bilirubin & $\begin{array}{l}<2 \mathrm{mg} / \mathrm{dl} \text { (1 point) } \\
2-3 \mathrm{mg} / \mathrm{dl} \text { ( } 2 \text { points }) \\
>3 \mathrm{mg} / \mathrm{dl} \text { ( } 3 \text { points })\end{array}$ \\
\hline Albumin & $\begin{array}{l}>3.5 \mathrm{~g} / \mathrm{dl} \text { ( } 1 \text { point }) \\
2.8-3.5 \mathrm{~g} / \mathrm{dl}(2 \text { points }) \\
<2.8 \mathrm{~g} / \mathrm{dl} \text { ( } 3 \text { points })\end{array}$ \\
\hline $\begin{array}{l}\text { Prothrombin } \\
\text { time } \\
\text { prolongation }\end{array}$ & $\begin{array}{l}<4 \mathrm{~s} \text { above control/INR }<1.7 \text { ( } 1 \text { point) } \\
4-6 \mathrm{~s} \text { above control/INR } 1.7-2.3 \text { ( } 2 \text { points) } \\
>6 \mathrm{~s} \text { above control/INR }>2.3 \text { ( } 3 \text { points) }\end{array}$ \\
\hline
\end{tabular}

Table 3b. CTP class

\begin{tabular}{clcl}
\hline Points & Class & 1-year survival & 2-year survival \\
\hline $5-6$ & A & $100 \%$ & $85 \%$ \\
$7-9$ & B & $81 \%$ & $57 \%$ \\
$10-14$ & C & $45 \%$ & $35 \%$ \\
\hline
\end{tabular}

aminase and PCR for tuberculosis, amylase and cytology, to exclude empyema, chylothorax, tuberculosis, pancreatitis and malignancy, respectively, in patients in whom another diagnosis is suspected.

In cases of SBEM, pleural fluid will have a high ANC level of $>250$ cells $/ \mathrm{mm}^{3}$ with positive fluid culture or ANC $>500$ cells $/ \mathrm{mm}^{3}$ with negative fluid culture without any evidence of pneumonia on chest X-ray, evidence of pleural effusion before an infectious episode and transudate
Table 4. Approach to the treatment of $\mathrm{HH}$

\begin{tabular}{|c|c|}
\hline $\begin{array}{l}\text { Reduce the } \\
\text { formation of } \\
\text { ascitic fluid }\end{array}$ & $\begin{array}{l}\text { Decrease salt and fluid intake } \\
\text { Diuretics } \\
\text { Somatostatin } \\
\text { Terlipressin } \\
\text { TIPS } \\
\text { Liver transplant }\end{array}$ \\
\hline $\begin{array}{l}\text { Prevent the } \\
\text { transfer of ascitic } \\
\text { fluid across the } \\
\text { diaphragm }\end{array}$ & $\begin{array}{l}\text { Paracentesis } \\
\text { Repair of diaphragmatic defects } \\
\text { CPAP }\end{array}$ \\
\hline $\begin{array}{l}\text { Drain the pleural } \\
\text { space }\end{array}$ & $\begin{array}{l}\text { Repeated thoracentesis } \\
\text { Indwelling pleural catheter } \\
\text { Pleurovenous shunt }\end{array}$ \\
\hline $\begin{array}{l}\text { Obliterate the } \\
\text { pleural space } \\
\text { (pleurodesis) }\end{array}$ & $\begin{array}{l}\text { Instillation of sclerosant through the chest } \\
\text { tube } \\
\text { Talc poudrage } \\
\text { VATS and pleurodesis* } \\
\text { 1) Chemical } \\
\text { 2) Mechanical }\end{array}$ \\
\hline
\end{tabular}

* May be combined with repair of diaphragmatic defects.

characteristics of the fluid during infection [26]. Inoculation of pleural fluid in blood culture bottle at bedside increases the sensitivity from 33 to $77 \%$ [11]. Patients who develop SBEM have lower levels of pleural fluid total protein of $<1 \mathrm{mg} / \mathrm{dl}$, low pleural fluid C3 and a higher ChildPugh-Turcotte (CTP) score (table $3 \mathrm{a}, \mathrm{b}$ ) than those who do not develop SBEM [40]. SBP has also been recognized as a risk factor for SBEM [7].

Although the diagnosis of $\mathrm{HH}$ may require exclusion of alternative diagnoses in some cases, demonstration of a peritoneal-pleural communication is not necessary in clinical practice unless surgical repair is being contemplated. The best test to confirm the communication between the pleural and the peritoneal space is scintigraphy which involves the intraperitoneal administration of a radioisotope and the migration of the radioisotope into the pleural cavity after few hours [41-43]. Transdiaphragmatic movement of ascitic fluid into the pleural cavity using contrast-enhanced ultrasonography with the contrast agent Sonazoid has also been reported [44]. Magnetic resonance imaging has also been used to detect diaphragmatic defects in $\mathrm{HH}$ [45]. These studies are not necessary to diagnose $\mathrm{HH}$ unless $\mathrm{HH}$ exists in the absence of ascites $[23,46]$ or there is a plan to close the communications between the peritoneal and pleural space by videoassisted thoracoscopy. 
Fig. 1. Proposed algorithm for the diagnosis of $\mathrm{HH}$. BNP = Brain natriuretic peptide; $\mathrm{CBC}=$ complete blood count; $\mathrm{ECHO}=$ echocardiography; $\mathrm{PT}=$ prothrombin time; $r / o=$ rule out.

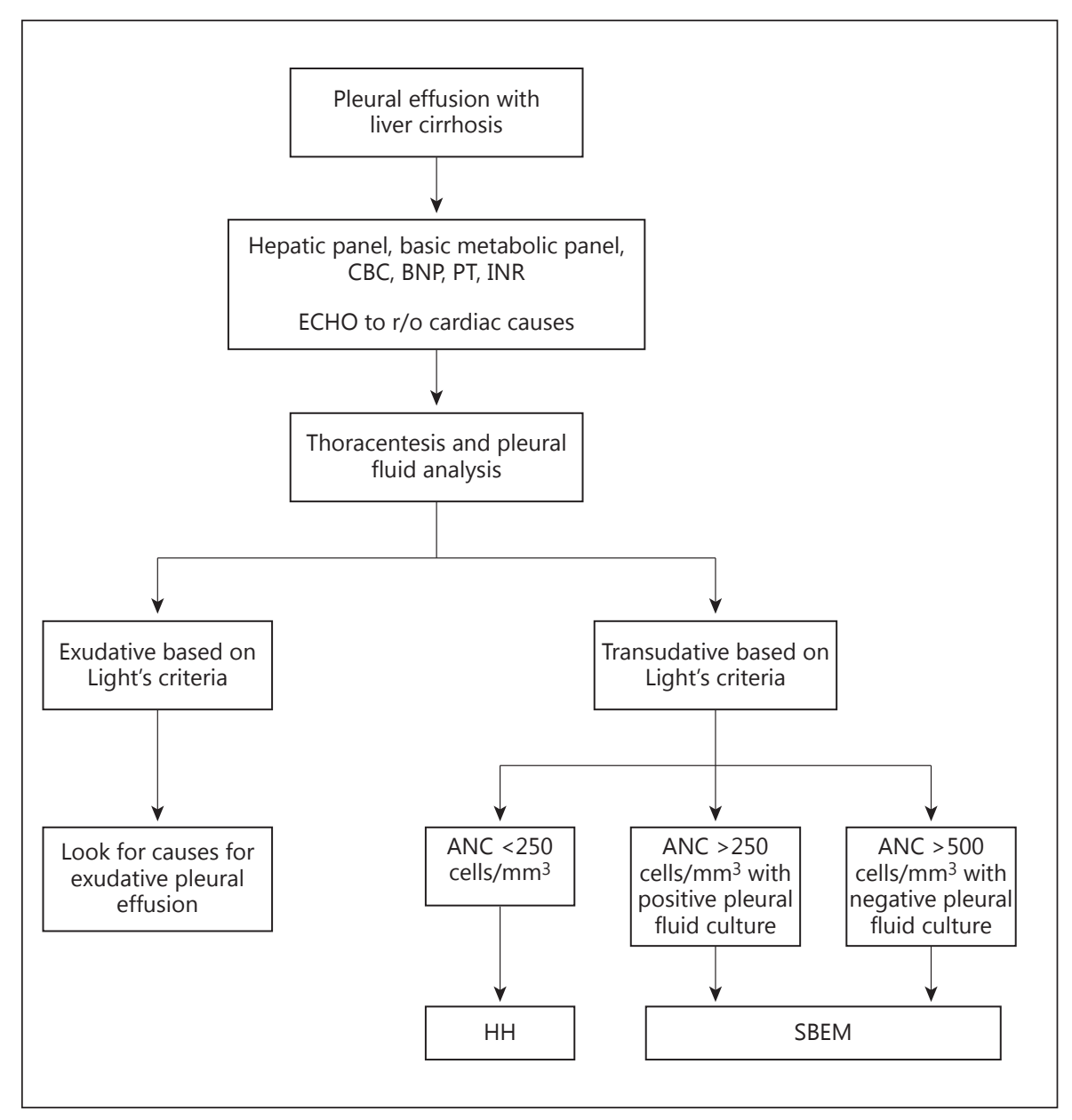

An echocardiography is generally performed to rule any cardiac causes of pleural effusions. In a study of 41 $\mathrm{HH}$ patients, an intrapulmonary shunt was detected in $78 \%$ (18 of 23) patients on contrast-enhanced echocardiography with agitated saline. There was also a high prevalence of diastolic dysfunction and left atrial enlargement in $\mathrm{HH}$ patients. However, the study did not mention how these patients were distinguished from left heart failure. The high prevalence of diastolic dysfunction can suggest that heart failure might have contributed to the development of pleural effusions [34]. The increased neurohormonal activity associated with cirrhosis leading to cardiac hypertrophy along with impaired relaxation has been speculated as the reason for diastolic dysfunction in cirrhotic patients $[47,48]$.

In addition to the above, basic metabolic panel, hepatic panel, brain natriuretic peptide and prothrombin time should be obtained in appropriate clinical setting. $\mathrm{CT}$ of the chest may be needed to exclude pulmonary, mediastinal or pleural causes or malignancies. The stepwise approach to the diagnosis of $\mathrm{HH}$ is shown in figure 1 .

\section{Management}

$\mathrm{HH}$ is an example of the porous diaphragm syndrome [14]. Portal hypertension results in the formation of ascitic fluid which moves across defects in the diaphragm and accumulates in the pleural space. Consequently, the treatment approach to $\mathrm{HH}$ consists of measures to reduce the formation of ascitic fluid, prevent the movement of ascitic fluid across the diaphragm, and drain or obliterate the pleural space. Table 4 shows the various therapeutic options for $\mathrm{HH}$.

Approximately $21-26 \%$ of $\mathrm{HH}$ cases are refractory to salt and fluid restriction and diuretics $[4,40]$ and warrant consideration of additional treatment measures. Ideally, 
Table 5. Advantages and disadvantages of the different treatment modalities for $\mathrm{HH}$

\begin{tabular}{|c|c|c|}
\hline Treatment & Advantages & Disadvantages \\
\hline $\begin{array}{l}\text { Medical } \\
\text { management }\end{array}$ & $\begin{array}{l}\text { - Cheap } \\
\text { - Noninvasive }\end{array}$ & $\begin{array}{l}\text { - High noncompliance rate } \\
\text { - } \text { Risk of acute kidney injury and renal failure } \\
\text { - Ineffective in refractory HH }\end{array}$ \\
\hline Thoracentesis & $\begin{array}{l}\text { - } \text { Relief of symptoms } \\
\text { - } \text { Allows pleural fluid analysis to rule out other } \\
\text { diagnoses like SBEM }\end{array}$ & $\begin{array}{l}\text { - Frequent requirement } \\
\text { - Complications like pneumothorax, hemothorax, } \\
\text { reexpansion pulmonary edema }\end{array}$ \\
\hline TIPS & $\begin{array}{l}\text { - Bridge to liver transplant } \\
\text { - Success rate of } 70-80 \%\end{array}$ & $\begin{aligned} \text { - } & \text { Post-TIPS hepatic encephalopathy } \\
\text { - } & \text { Shunt occlusion and thrombosis } \\
\text { - } & \text { Poor survival in MELD }>15, \text { CTP class C and } \\
& \text { high pre-TIPS creatinine of }>2 \mathrm{mg} / \mathrm{dl}\end{aligned}$ \\
\hline Pleurodesis & $\begin{array}{l}\text { - Repair of diaphragmatic defects can be performed } \\
\text { - Success can be increased with CPAP, somatostatin } \\
\text { - Considered in patients when TIPS is contraindicated }\end{array}$ & $\begin{array}{l}\text { - Repeated procedures are needed } \\
\text { - General anesthesia needed for VATS } \\
\text { - Complications like empyema, sepsis, septic shock } \\
\text { - Increase bleeding risk with mechanical pleurodesis } \\
\text { - Cannot be performed in trapped lung }\end{array}$ \\
\hline $\begin{array}{l}\text { Surgical repair } \\
\text { of diaphragmatic } \\
\text { defects }\end{array}$ & - Increase success of pleurodesis & $\begin{array}{l}\text { - Not always visualized } \\
\text { - Invasive }\end{array}$ \\
\hline Liver transplant & - Most effective management option & - Long waiting time \\
\hline
\end{tabular}

liver transplantation is the best treatment option for these patients $[49,50]$; however, most of the patients are not candidates [51] and most of those who are eligible die while waiting for a transplant $[52,53]$. Treatment measures other than liver transplantation may not only provide relief from dyspnea but also improve patient survival and serve as a bridge to liver transplantation. In a study of $52 \mathrm{HH}$ patients [54], resolution of hydrothorax for at least 3 months was reported in $37.5 \%$ of patients with chemical pleurodesis and in $42.9 \%$ after surgical intervention, with an overall success rate of $50 \%$. The median survival of patients with intervention success (22.5 months) was significantly longer than in those with intervention failure (5.4 months) and supportive care (6.3 months). The advantages and disadvantages of different therapeutic options are shown in table 5.

\section{Reduce the Formation of Ascitic Fluid}

\section{Medical Management}

The primary goal of $\mathrm{HH}$ treatment is to achieve a negative sodium balance by restricting sodium intake and pharmacological therapy using diuretics [55]. Sodium intake in the diet should be $<2,000 \mathrm{mg} /$ day. A combination of loop diuretics (furosemide) and Aldactone receptor antagonist (spironolactone) is used to achieve a renal excretion of at least $120 \mathrm{mEq}$ sodium/day [56].

Diuretics can be increased in a stepwise manner by doubling the dose every 5 days if there is no response to treatment, and noncompliance with diet and medications have been excluded. Maximum doses of spironolactone and furosemide are up to 400 and $160 \mathrm{mg} /$ day, respectively $[57,58]$. Patients who do not respond to medical therapy are considered to have a refractory hydrothorax. It is a clinical challenge to manage refractory hydrothorax as most of these patients have associated renal dysfunction along with impaired liver function. Aggressive diuresis is usually complicated by renal insufficiency and electrolyte imbalance and is poorly tolerated in these patients. In a retrospective study of 405 patients with cirrhosis admitted over a 5-year period, 7 of 27 (25.9\%) HH patients were refractory to medical treatment [4]. In another prospective study of 60 cirrhotic patients, $13(21.7 \%) \mathrm{HH}$ patients were considered refractory [40].

A recent case report showed that intravenous terlipressin, which is known to be beneficial in the hepatorenal syndrome, might also be effective in $\mathrm{HH}$ [59]. Intravenous octreotide has also been successful for $\mathrm{HH}$ treatment [60]. A case of refractory $\mathrm{HH}$, which resolved after 
adding the $\alpha$-adrenergic agonist midodrine to octreotide, has also been reported [61]. Octreotide can potentiate the beneficial hemodynamic and renal effects of midodrine in decompensated cirrhosis [62]. The hypothesis behind the use of these agents is to reduce splanchic blood flow thereby decreasing peritoneal and pleural fluid accumulation. However, there are not enough data to support the routine use of these drugs in the management of $\mathrm{HH}$. Moreover, such treatment may be costly and impractical on an outpatient basis because of the intravenous route of administration.

\section{Transjugular Intrahepatic Portosystemic Shunt}

Transjugular intrahepatic portosystemic shunt (TIPS) is a procedure that creates an anastomosis between the portal and the hepatic vein. It decompresses the splanchic vascular bed, thereby decreasing portal venous pressure. The efficacy of TIPS in HH has been reported in several retrospective nonrandomized studies and case reports [33, 63-70].

Table 6 compares and summarizes the results of these studies. A total of 332 patients were included in these studies. The overall response rate, which was defined as complete or partial response with respect to the resolution of the hydrothorax, an improvement in respiratory symptoms and a decrease in the frequency of thoracentesis, was found to be $73.71 \%$, with a range of $58-82 \%$. The mean complete and partial response rates were 55.9 and $24.6 \%$, respectively. Spencer et al. [68] showed that the complete resolution of the hydrothorax on a radiograph is not required for a patient to be free of symptoms.

The major complication of the TIPS procedure is the development or worsening of hepatic encephalopathy. Compounds that require hepatic detoxification in the portal circulation bypass the liver through TIPS and enter the systemic circulation causing post-TIPS encephalopathy. In the largest series evaluating TIPS in HH done by Dhanasekaran et al. [70], hepatic encephalopathy developed in $15 \%$ of the patients. The other complications included infection in $8.2 \%$; procedure-related bleeding in $6.8 \%$, acute renal failure in $2.7 \%$ and the acute respiratory distress syndrome in $2.7 \%$. The study did not specify the criteria for the diagnosis of the acute respiratory distress syndrome. Given the high prevalence of diastolic heart failure in $\mathrm{HH}$ patients [34], these patients might have developed pulmonary edema secondary to heart failure due to a sudden increase in preload after TIPS.

The incidence of hepatic encephalopathy ranged anywhere between 5 and $50 \%$ in different studies, with an average of $26.7 \%$ [33, 65-70]. This could be because of the retrospective nature of these studies making it difficult to assess the grade of encephalopathy after TIPS. Shunt occlusion or thrombosis is also one of the late complications of the TIPS procedure causing reaccumulation of pleural fluid and ascites. The patency of covered stents seems to be better than that of uncovered stents. In a prospective randomized study that compared the patency rates of covered and uncovered stents, the patency rate was found to be better with covered stents (76\%) then with uncovered stents (36\%) [71].

The average 30 -day mortality was around $18.6 \%$. The factors associated with mortality after TIPS for $\mathrm{HH}$ are age $>60$ years, CTP class $\mathrm{C}$, high pre-TIPS model for end-stage liver disease (MELD) score $>15$ (table 7) and high pre-TIPS creatinine levels $>2 \mathrm{mg} / \mathrm{dl}[33,68,70]$. The 1-year survival rates mentioned in three studies ranged from 41 to $64 \%$, with a mean of $52.3 \%$ [33, 69, $70]$. The highest survival rate was seen by Siegerstter et al. [33]. The clinical response, age $<60$ years and preTIPS MELD score were significantly correlated with survival $[33,70]$.

TIPS does not improve the overall prognosis of patients with end-stage liver disease. In carefully selected patients with MELD score $<15$, CTP A or B and age $<60$ years, TIPS can be an effective treatment of refractory hydrothorax and can be used as a bridge to liver transplantation. The absolute contraindications to TIPS include cardiac conditions that may worsen after the procedure like congestive heart failure (CHF), severe tricuspid regurgitation and severe pulmonary hypertension with mean pulmonary pressures $>45 \mathrm{~mm} \mathrm{Hg}$ [72]. In patients with high predicted 30-day mortality rates with MELD $>15$ and CTP class C, TIPS should only be performed in the absence of other options. Patients with high MELD score have severe hepatic dysfunction; performing TIPS in these patients could precipitate liver failure due to shunting of blood away from the liver leading to hepatic ischemia. TIPS is contraindicated in patients with hepatic encephalopathy only if hepatic encephalopathy is uncontrollable with medical therapy. Only $5 \%$ of cases require occlusion of TIPS or a reduction in the TIPS caliber to control encephalopathy. Relative contraindications to TIPS include portal venous obstruction, large hepatic tumors, extensive polycystic liver disease, hepatic vein obstruction, severe coagulopathy (INR $>5$ ) and thrombocytopenia $<20,000 / \mathrm{cm}^{3}$. Patients with significant coagulopathy may be able to undergo TIPS following treatment with clotting factors or platelets [72]. 
Table 6. Results of TIPS in refractory $\mathrm{HH}$

\begin{tabular}{|c|c|c|c|c|c|c|c|c|c|c|c|}
\hline $\begin{array}{l}\text { First author } \\
\text { year } \\
\text { country }\end{array}$ & $\begin{array}{l}\text { Total } \\
\mathrm{n}\end{array}$ & & $\begin{array}{l}\text { Age } \\
\text { years }\end{array}$ & Sex & Success rate & Success defined & $\begin{array}{l}\text { TIPS } \\
\text { patency }\end{array}$ & $\mathrm{HE}$ & $\begin{array}{l}\text { Follow-up } \\
\text { duration }\end{array}$ & $\begin{array}{l}\text { 30-day } \\
\text { mor- } \\
\text { tality } \\
\%\end{array}$ & $\begin{array}{l}\text { 1-year } \\
\text { probable } \\
\text { survival } \\
\%\end{array}$ \\
\hline $\begin{array}{l}\text { Strauss [64] } \\
1994 \\
\text { USA }\end{array}$ & 5 & $\begin{array}{l}\text { CTP: } \\
\text { C } 5\end{array}$ & & & $\begin{array}{l}\text { Overall: } 80 \% \\
\text { CR: } 40 \% \\
\text { PR: } 40 \% \\
\text { NR: } 20 \%\end{array}$ & & $\begin{array}{l}\text { Occlusion: } \\
60 \%(3 / 5)\end{array}$ & & & 0 & \\
\hline $\begin{array}{l}\text { Gordon [65] } \\
1997 \\
\text { USA }\end{array}$ & 24 & $\begin{array}{l}\text { CTP: } \\
\text { B } 5 \\
\text { C } 19\end{array}$ & 58.2 & $\begin{array}{l}\text { M } 14 \\
\text { F } 10\end{array}$ & $\begin{array}{l}\text { Overall: } 79 \% \\
\text { CR: } 58.3 \% \\
\text { PR: } 20.8 \%\end{array}$ & $\begin{array}{l}\text { CR: resolution of hydrothorax } \\
\text { or resp. symptoms with } \\
\text { reduction in pleural fluid } \\
\text { PR: reduced frequency of } \\
\text { thoracentesis with improved } \\
\text { resp. symptoms }\end{array}$ & $\begin{array}{l}\text { TIPS } \\
\text { patency: } \\
87.5 \% \\
\text { Occlusion/ } \\
\text { stenosis: } 3 / 24\end{array}$ & $\begin{array}{l}\text { HE: } \\
37.5 \% \\
(9 / 24)\end{array}$ & $\begin{array}{l}7.2 \text { months } \\
(0.25- \\
49 \text { months })\end{array}$ & $20.8^{\mathrm{a}}$ & $17^{\mathrm{b}}$ \\
\hline $\begin{array}{l}\text { Jeffries [66] } \\
1998 \\
\text { USA }\end{array}$ & 12 & $\begin{array}{l}\text { CTP: } \\
\text { A } 1 \\
\text { B } 5 \\
\text { C } 6 \\
\text { R: } 10 \\
\text { L: } 2\end{array}$ & $\begin{array}{l}54 \\
(41-72)\end{array}$ & $\begin{array}{l}\text { M } 4 \\
\text { F } 8\end{array}$ & $\begin{array}{l}\text { Overall: } 58 \% \\
\text { CR: } 41.6 \% \\
\text { PR: } 16.6 \%\end{array}$ & $\begin{array}{l}\text { CR: improvement in resp. } \\
\text { status with no further } \\
\text { thoracentesis } \\
\text { PR: improvement in resp. } \\
\text { status with a reduction in the } \\
\text { frequency of thoracentesis }\end{array}$ & $\begin{array}{l}\text { Occlusion/ } \\
\text { stenosis: } \\
7 / 12\end{array}$ & $\begin{array}{l}\text { HE: } 33 \% \\
(4 / 12)\end{array}$ & $\begin{array}{l}173 \text { days } \\
\text { (7-926 days) }\end{array}$ & 25 & $18^{\mathrm{b}}$ \\
\hline $\begin{array}{l}\text { Chalasani [67] } \\
2000 \\
\text { USA }\end{array}$ & 129 & $\begin{array}{l}24-\mathrm{HH} \\
\text { CTP: } \\
\text { B 30\% } \\
\text { C } 70 \%\end{array}$ & $\begin{array}{l}54.8 \pm \\
10.7\end{array}$ & $\begin{array}{l}\text { M } 70 \\
\text { F } 30\end{array}$ & & & $\begin{array}{l}\text { Shunt } \\
\text { dysfunction: } \\
26 \%\end{array}$ & HE: $20 \%$ & 57.2 months & 23 & 56 \\
\hline $\begin{array}{l}\text { Siegerstetter } \\
{[33]} \\
2001 \\
\text { Germany }\end{array}$ & 40 & $\begin{array}{l}\text { CTP: } \\
\text { B } 24 \\
\text { C } 16 \\
\text { R: } 33 \\
\text { L: } 7\end{array}$ & $\begin{array}{l}54 \\
(31-70)\end{array}$ & $\begin{array}{l}\text { M } 21 \\
\text { F } 19\end{array}$ & $\begin{array}{l}\text { Overall: } 82 \% \\
\text { CR: } 71 \% \\
\text { PR: } 12 \%\end{array}$ & $\begin{array}{l}\text { CR: lack of pleural effusion } \\
\text { PR: lack of thoracentesis }\end{array}$ & $\begin{array}{l}\text { Occlusion/ } \\
\text { stenosis: } \\
20 / 40\end{array}$ & $\begin{array}{l}\text { HE: } 5 \% \\
(2 / 40)\end{array}$ & $\begin{array}{l}16 \pm 14 \\
\text { months } \\
\text { ( } 1 \text { day to } \\
54 \text { months) }\end{array}$ & & 64 \\
\hline $\begin{array}{l}\text { Spencer [68] } \\
2002 \\
\text { USA }\end{array}$ & 21 & $\begin{array}{l}\text { CTP: } \\
\text { B } 7 \\
\text { C14 }\end{array}$ & $\begin{array}{l}56 \\
(34-74)\end{array}$ & $\begin{array}{l}\text { M } 12 \\
\text { F } 9\end{array}$ & $\begin{array}{l}\text { Overall: } 74 \% \\
\text { CR: } 64 \% \\
\text { PR: } 10 \%\end{array}$ & $\begin{array}{l}\text { CR: symptom and effusion } \\
\text { resolution } \\
\text { PR: improved symptom and } \\
\text { effusion }\end{array}$ & $\begin{array}{l}\text { Stenosis: } \\
3 / 21 \\
\text { TIPS patency: } \\
49 \% \\
\text { (6 months) }\end{array}$ & $\begin{array}{l}\text { HE: } 50 \% \\
(9 / 18)\end{array}$ & $\begin{array}{l}7.2 \text { months } \\
(1-1,641 \\
\text { days })\end{array}$ & 29 & $43^{b}$ \\
\hline $\begin{array}{l}\text { Wilputte [69] } \\
2007 \\
\text { Belgium }\end{array}$ & 28 & $\begin{array}{l}\text { CTP: } \\
\text { B } 43 \\
\text { C } 57\end{array}$ & & & $\begin{array}{l}\text { Overall: } 68 \% \\
\text { CR: } 57 \% \\
\text { PR: } 68 \%\end{array}$ & $\begin{array}{l}\text { CR: radiological and } \\
\text { echographic disappearance of } \\
\text { hydrothorax } \\
\text { PR: reduction in the volume of } \\
\text { effusion and improvement in } \\
\text { symptoms }\end{array}$ & & & & 14 & 41.2 \\
\hline $\begin{array}{l}\text { Dhanasekaran } \\
{[70]} \\
2010 \\
\text { USA }\end{array}$ & 73 & $\begin{array}{l}\text { Pre-TIPS } \\
\text { MELD: } \\
<15: 32.8 \% \\
>15: 67.2 \%\end{array}$ & 55.62 & $\begin{array}{l}\text { M } 40 \\
\text { F } 33\end{array}$ & $\begin{array}{l}\text { Overall: } 75 \% \\
\text { CR: } 60 \% \\
\text { PR: } 15 \% \\
\text { (at } 6 \text { months) }\end{array}$ & $\begin{array}{l}\text { CR: absence of symptoms no } \\
\text { further thoracocentesis. } \\
\text { PR: improvement in symptoms } \\
\text { with decreased need for } \\
\text { thoracocentesis }\end{array}$ & $\begin{array}{l}\text { Revision of } \\
\text { TIPS } 24.7 \%\end{array}$ & $\begin{array}{l}\text { HE: } \\
15.1 \%\end{array}$ & $\begin{array}{l}759 \text { days } \\
\text { (range } \\
1-4,308 \text { ) }\end{array}$ & 19 & 48 \\
\hline Mean & 332 & & & & $\begin{array}{l}\text { Overall: } 73.71 \\
\text { CR: } 55.9 \% \\
\text { PR: } 24.6 \%\end{array}$ & & & $26.7 \%$ & & $18.6 \%$ & $52.3 \%$ \\
\hline
\end{tabular}

$\mathrm{CR}=$ Complete response; $\mathrm{HE}=$ hepatic encephalopathy $\mathrm{L}=$ left pleural effusion; $\mathrm{PR}=$ partial response; $\mathrm{R}=$ right pleural effusion .

a45-day mortality.

${ }^{\mathrm{b}}$ Cumulative survival over entire course of study. 
Table 7. MELD score

\begin{tabular}{ll}
\hline Calculation $\quad$ MELD $=$ & $3.78[$ ln serum bilirubin $(\mathrm{mg} / \mathrm{dl})]$ \\
& $+11.2[$ ln INR $]$ \\
& $+9.57[$ ln serum creatinine $(\mathrm{mg} / \mathrm{dl})]$ \\
& +6.43 \\
\hline Interpretation $\quad 3$-month mortality based on MELD score: \\
$\geq 40: 71.3 \%$ mortality \\
30-39: $52.6 \%$ mortality \\
$20-29: 19.6 \%$ mortality \\
$10-19: 6.0 \%$ mortality \\
$<9: 1.9 \%$ mortality
\end{tabular}

\section{Liver Transplant}

Liver transplant is the treatment of $\mathrm{HH}$ and is indicated in refractory hydrothorax, hydrothorax with poor liver function (MELD >15) and after a SBEM episode. In a study by Xiol et al. [73], postoperative mortality, longterm survival, days of mechanical ventilation after surgery and transfusion requirements were similar in the hydrothorax group $(\mathrm{n}=28)$ and in the control group $(\mathrm{n}=56)$ who underwent orthotropic liver transplantation for reasons other than $\mathrm{HH}$. There was no difference in survival between patients with and without SBEM. The mean survival of patients transplanted because of $\mathrm{HH}$ was 114 months, with $82 \%$ patients were alive at 1 year and $70 \%$ at 5 years. Pleural effusion persisted in 9 patients 1 month after orthotropic liver transplantation but only in 1 patient after 3 months, which was attributed to heart failure.

Similar findings were also observed in another study that compared pre- and posttransplant symptoms and management of patients with $\mathrm{HH}$ and end-stage liver disease [74]. Of 11 patients, $73 \%$ needed thoracentesis in the pretransplant course, with 55\% requiring more than once. None of the patients required thoracentesis in the posttransplant course. When this group of patients was compared with two control groups of 11 patients each (patients with tense ascites with no hydrothorax and patients without ascites), no significant differences were observed in terms of duration of mechanical ventilation, intensive care unit stay, inhospital stay, sepsis and early postoperative death. One-year survival was also similar in all groups.

Presence of $\mathrm{HH}$ does not lead to more postoperative complications, and long-term survival is similar to other indications of liver transplantation. Liver transplantation is an excellent therapeutic option for patients with refractory $\mathrm{HH}$. The challenge is to determine the appropriate treatment to bridge them to liver transplantation when TIPS is not a good option. In such patients, other treatment modalities like pleurodesis with or without repair of diaphragmatic defects or an indwelling pleural catheter can be considered. Pleurodesis is not considered a contraindication to liver transplantation.

Liver transplantation has also shown to have good outcome in SBEM. In a small series of 24 patients with SBEM, survival was $100 \%$ in all of the 5 patients who underwent transplantation [11]. Though antibiotics, especially thirdgeneration cephalosporins, are required in these patients, SBEM should be considered an indication for orthotopic liver transplant irrespective of SBP.

\section{Prevent the Transfer of Ascitic Fluid across the Diaphragm}

\section{Paracentesis}

Paracentesis is a simple and well-tolerated procedure and should be attempted in all patients with $\mathrm{HH}$ prior to thoracentesis to prevent the rapid accumulation of fluid in the pleural space after thoracentesis due to decreased intrathoracic pressure. Large volume paracentesis can also provide symptomatic relief of dyspnea in patients with $\mathrm{HH}$ even before thoracentesis is performed. A study by Angueira and Kadakia [75] demonstrated a statistically significant increase in total lung capacity and functional residual capacity with symptomatic improvement within $2 \mathrm{~h}$ of paracentesis with an average fluid removal of 3.5 liters. Another study of 31 cirrhotic patients with acute lung injury on mechanical ventilation reported a decrease in intra-abdominal pressure and an increase in $\mathrm{PaO}_{2} / \mathrm{FiO}_{2}$ and end-expiratory lung volume without hemodynamic disturbances following paracentesis of an average of 3.6 liters [76].

\section{Peritoneovesical Shunt}

A peritoneovesical shunt known as ALFA pump system is a new investigational technique that has been approved in Europe for the management of ascites but has not yet been approved in the United States [77]. It is implanted subcutaneously and pumps excess peritoneal fluid into the bladder where the patient can eliminate it through normal urination. Reduction in ascites may also decrease $\mathrm{HH}$ formation. However, it is still in the experimental stage and has only been used in phase 3 clinical trials so far. 
Repair of Diaphragmatic Defects

Repair of the diaphragmatic defects to reduce the flux of fluid from the peritoneal to the pleural cavity has been shown to be effective in recurrent $\mathrm{HH}$. These diaphragmatic defects can be visualized thoracoscopically or with the use of dye or pneumoperitoneum. Ibi et al. [78] reported 2 cases of refractory $\mathrm{HH}$ that were successfully treated with repair of diaphragmatic defects with sutures, biological glue and mesh during video-assisted thoracoscopic surgery (VATS). The defects were explored using dye and pneumoperitoneum. There was no recurrence of hydrothorax in both cases at the 1-year follow-up. In a surgical series of 10 patients, Huang et al. [79] reported successful control of $\mathrm{HH}$ with thoracoscopic pleural mesh onlay reinforcement to repair the diaphragmatic fenestrations. There was no recurrence in any patient after a mean follow-up of 7.7 months. Two patients died of hemorrhage from esophageal varices 2 months postoperatively.

Repair of the defects has also been combined with pleurodesis during VATS to increase the success of the procedure. The success rate increased from 47.6 to $60 \%$ after repair of the diaphragmatic defects in a study of 18 patients with refractory $\mathrm{HH}[80]$. However, these defects cannot be visualized in all patients. Luh and Chen [81] visualized diaphragmatic defects in only 2 of $12(16.7 \%)$ patients. which were repaired with sutures. Similarly, in other studies, diaphragmatic defects were visualized in 12 and $22.2 \%$ of the cases, respectively $[82,83]$, and in some series, diaphragmatic defects could not be visualized at all during VATS [84].

Although this approach appears encouraging, it is limited by the lack of visualization of the diaphragmatic defects. However, if a patient is taken for VATS pleurodesis then an attempt to visualize the diaphragmatic fenestrations and repair, if possible, should be considered to increase the successful outcome of pleurodesis.

\section{Continuous Positive Airway Pressure}

Continuous positive airway pressure (CPAP) decreases the negative pressure in the thoracic cavity, thereby decreasing the pressure gradient between peritoneal and pleural cavities and thus preventing the flux of fluid from the abdomen to the pleural space. A case of resistant $\mathrm{HH}$ with marked improvement following nasal CPAP treatment during sleep has been reported [85]. In one study, CPAP was combined with pleurodesis to improve the success rate by increasing positive intrathoracic pressure and reversing the peritoneal-pleural pressure gradient. This reversing of the pressure gradient encourages the backward flow of fluid from the pleural to the peritoneal space, thereby allowing more time for the pleural surfaces to be dry to achieve pleurodesis [86]. However, further large studies are needed to validate the use of CPAP solely for the management of refractory $\mathrm{HH}$, but a combination of CPAP with other techniques like pleurodesis appears promising theoretically. Also, increased risk of aspiration with the use of CPAP in the setting of hepatic encephalopathy should be kept in mind.

\section{Drain the Pleural Space}

\section{Repeated Thoracentesis}

Patients with symptomatic refractory hydrothorax require thoracentesis for relief of dyspnea symptoms. The procedure is generally well tolerated, however, if thoracentesis is required every 2-3 weeks inspite of maximal medical therapy then alternative treatments should be considered, as the procedure-related complications, including pneumothorax and hemothorax, increase with the increased frequency of procedures. As mentioned before, when ascites is present, paracentesis should always be performed before thoracentesis to minimize the recurrence of hydrothorax immediately after thoracentesis.

There is no consensus for the maximal volume of pleural fluid to be drained in a single thoracentesis procedure. There have been postulations to drain less than or equal to 2 liters of pleural fluid to prevent reexpansion pulmonary edema, but no randomized controlled studies have been conducted to determine the maximum amount of fluid that can be drained in a single setting. Large volume thoracentesis (>1-6.55 liters) in a prospective study showed that of 185 patients submitted to thoracentesis, only 1 patient $(0.5 \%)$ experienced edema with clinical manifestations, and 4 (2.2\%) developed compatible radiographic abnormalities. The clinical reexpansion pulmonary edema after large-volume thoracentesis was independent of the volume of fluid removed [87]. However, pleural manometry was routinely performed and the procedure was terminated if pleural pressures dropped to $-20 \mathrm{~cm} \mathrm{H}_{2} \mathrm{O}$ or the patient developed chest discomfort. The development of chest discomfort that has been correlated with a reduction in pleural pressure should be a sign to terminate thoracentesis [88].

Coagulopathy should not be considered as a contraindication to thoracentesis and paracentesis. A retrospective study of 608 patients undergoing thoracentesis and paracentesis did not show any increased bleeding in patients with mild-to-moderate coagulopathy with either 
prothrombin time or partial thromboplastin time up to twice the midpoint normal range, or a platelet count of 50-99,000/ $\mu$; authors concluded that prophylactic plasma or platelet transfusions are not necessary. However, patients with markedly elevated serum creatinine levels $>6.0 \mathrm{mg} / \mathrm{dl}$ had a significantly greater average hemoglobin loss of $>2 \mathrm{~g} / \mathrm{dl}$ than patients with normal serum creatinine levels. Overall, red cell transfusions were required only in $0.2 \%$ of events [89].

\section{Chest Tube}

A chest tube should not be placed in $\mathrm{HH}$ patients because high chest tube output and massive loss of fluid can lead to renal dysfunction and electrolyte disturbances [89]. Because of the rapid reaccumulation of fluid in the pleural space as well as the high output, removal of the chest tube becomes difficult once it is placed.

A retrospective review of 17 patients (admitted over a 10 -year period) with $\mathrm{HH}$ and placement of a chest tube showed that 16 of 17 patients had at least one complication and 12 patients had more than one complication. Eleven patients had acute kidney injury, 7 patients had pneumothorax and 5 patients had empyemas [91]. The largest retrospective study so far that analyzed the outcome of chest tube placement in 59 cirrhotic patients was reported by Liu et al. [92], however it also included patients who received chest tubes for empyema as well as pneumothorax. The study showed that $80 \%$ of patients had one or more complications like renal dysfunction, electrolyte imbalances and infection. Mortality was $16 \%$ in CTP class B patients and up to $40 \%$ among CTP C patients. Deaths while having a chest tube in place were deemed by the authors to be secondary to complications from having it in place, rather than to adverse effects from the tube placement procedure.

Even in cases of SBEM, patients have been treated with antibiotics alone without any requirement of a chest tube. Since chest tube insertion is associated with higher adverse events, as discussed before, and most cases of SBEM respond to antibiotic therapy [11], a chest tube should not be placed in patients with SBEM unless they meet criteria for placing a chest tube like frank pus or $\mathrm{pH}<7.2$.

\section{Indwelling Pleural Catheter}

Tunneled pleural catheter (PleurX) insertion has been shown to be effective in the management of malignant pleural effusions with symptomatic relief of symptoms and spontaneous pleurodesis in some patients [93]. It is placed under local anesthesia. A case of refractory $\mathrm{HH}$ after TIPS that was managed effectively with PleurX cath- eter insertion had symptomatic improvement, and drainage volume gradually decreased. Spontaneous pleurodesis was achieved without any recurrent pleural effusion at the 6-month follow-up after catheter removal. The catheter was removed due to methicillin-resistant Staphylococcus aureus cellulitis at the insertion site [94].

Chalhoub et al. [95] studied the effectiveness of the PleurX catheter in the management of nonmalignant pleural effusions in a retrospective analysis of patients who underwent PleurX catheter placement for recurrent pleural effusions between 2003 and 2009. Patients were divided into two groups. Group I $(\mathrm{n}=23)$ included patients with nonmalignant pleural effusions and group II $(\mathrm{n}=41)$ included patients with malignant pleural effusions. The diagnoses in group I included CHF $(\mathrm{n}=13)$, $\mathrm{HH}(\mathrm{n}=8)$, traumatic bloody $(\mathrm{n}=1)$, and idiopathic exudative effusion $(n=1)$. The diagnoses in group II included lung cancer $(n=20)$, breast cancer $(n=11)$, colon cancer $(n=5)$, prostate cancer $(n=2)$, B-cell lymphoma $(n=$ 2 ) and mesothelioma $(n=1)$. The time to pleurodesis was higher in group I $(110.8+41$ days) than in group II (36 + 12 days). Time to pleurodesis was significantly shorter in HH compared to CHF (73.6 + 9 vs. $113+36$ days, respectively). The authors suggested that the shorter time to pleurodesis in $\mathrm{HH}$ patients compared to CHF patients could be related to increased levels of circulating inflammatory mediators in subjects with cirrhosis favoring more rapid pleural symphysis. The mean satisfaction score was similar in both groups. Among subjects who were alive 3 months after catheter removal, none had recurrence of their pleural effusion. There was 1 case of exit-site infection in a patient with $\mathrm{HH}$. There were 3 deaths in the nonmalignant group and 10 deaths in the malignant group. In group I, 3 deaths occurred before the removal of the PleurX catheter. One patient died of myocardial infarction and resulting cardiogenic shock, and 2 patients died of respiratory failure related to hepatic encephalopathy. According to the authors, none of the deaths were related to pleural effusion and catheter-related complications. However, the MELD score or CTP class of patients at baseline were not mentioned in the study.

Another study by Kilburn et al. [96] identified 14 patients who received tunneled pleural catheter placement for the treatment of refractory $\mathrm{HH}$ between October 2007 and January 2010. Of 14 cases, 8 patients in whom the PleurX catheter was placed as a bridge to TIPS or transplantation, 5 (62.5\%) achieved spontaneous pleurodesis with successful PleurX catheter removal without transplant. Empyema occurred in 2 patients (25\%), requiring removal of the catheter in 1 patient. 
Though one would expect that the reported complications of repeated fluid removal after placement of a chest tube leading to renal injury should also be seen with the PleurX catheter, the lower incidence of adverse events could be because of intermittent and small amounts of fluid removed each time via the PleurX catheter. However, the long-term requirement of a tunneled pleural catheter in nonmalignant pleural effusions increases the chance of infectious complications. In a small series of patients who received the PleurX catheter for CHF, 2 of 5 patients (40\%) developed empyema and 1 patient developed loculations [97]. Even though placement of the PleurX catheter for refractory hydrothorax looks promising, data are limited and further studies are required to compare the effectiveness of the PleurX catheter with other treatment modalities.

\section{Pleurovenous Shunt}

A few case reports have used a pleurovenous shunt for the management of $\mathrm{HH}[98,99]$. Artemiou et al. [100] showed the effectiveness of pleurovenous shunts in 12 patients with chronic nonmalignant right-sided pleural effusions. Out of these, 6 had HH. Patients were followed for a period of 13.3 months (1-40 months). All shunts were patent and none of the patients required further treatment for pleural effusion. However, long-term patency and complications of pleurovenous shunts remain currently unknown.

\section{Obliterate the Pleural Space}

\section{Pleurodesis}

Pleurodesis is a procedure in which the space between the visceral and parietal pleura is obliterated with the use of an agent that acts as an irritant to cause inflammation on the pleural surfaces. The irritant is administered through a chest tube or during thoracoscopy (medical or VATS). It difficult to achieve pleurodesis because of the dilution of the sclerosing agent and the inability to keep the pleural surfaces juxtaposed due to rapid fluid accumulation in $\mathrm{HH}$ because of continuous passage of ascitic fluid from the abdominal cavity.

Table 8 shows the comparison of various studies of pleurodesis for $\mathrm{HH}$ management [80-83, 86, 101-105]. The most common sclerosing agent that has been used in different studies is talc. However, a few studies have used tetracycline, OK-432 with minocycline, Vibramycin, povo-iodine and bleomycin $[83,104,105]$. The overall success rate of pleurodesis in different studies, which was defined as radiographic disappearance of pleural fluid and relief of symptoms, has been between 47 and 100\%. The average overall success rate was $74.7 \%$ and the average recurrence rate, requiring repeated pleurodesis, was $24.5 \%$. The mean duration of chest tube drainage was 8.7 days.

\section{Chemical Pleurodesis}

Chemical pleurodesis can be done by instillation of a sclerosing agent through a chest tube as well as during medical thoracoscopy. A retrospective Korean study used talc, taurolidine and Viscum album in 3, 2 and 6 patients, respectively, for pleurodesis via a chest tube [106]. None of the patients was considered for TIPS as it was not available at the institution where the study was performed. The median MELD score was 16 (9-21). The overall success rate was $72.7 \%$ with a recurrence rate of $27 \%$. Patients who achieved success of the treatment showed significantly better outcomes than patients who did not achieve success. Complications included low grade fever and leukocytosis (100\%), pneumonia (9.1\%), pneumothorax (36.4\%), azotemia/acute renal failure (54.6\%) and hepatic encephalopathy $(36.4 \%)$. The procedure-related mortality due to occurrence of acute renal failure was $45.5 \%$.

Only one study used medical thoracoscopy for pleurodesis [104]. However, it is unclear why medical thoracoscopy was done when talc was used as slurry after medical thoracoscopy. Pleurodesis was performed in 23 patients using talc (asbestos free), Vibramycin and povoiodine with an overall success rate of $75 \%$. All patients were CTP B. The recurrence rate was $20 \%$ and mean duration of chest tube drainage was $9.8 \pm 2.3$ days. However, pleurodesis had to be repeated at least once in all patients (see legend at the bottom of table 8). Moreover, somatostatin was used in all patients to reduce drainage volume and shorten the duration of chest tube removal. As mentioned before, somatostatin reduces splanchic blood flow and the portosystemic pressure gradient, thereby reducing peritoneal and pleural fluid accumulation. Somatostatin was preferred instead of TIPS in the study as per authors somatostatin has few and minor side effects compared to TIPS. Early complications after the procedure included surgical emphysema (18.2\%), superficial wound infection (9.1\%), mild thoracic pain (4.5\%) and a single patient (4.5\%) with prehepatic coma 4 days after the procedure that was treated medically. Two (10.5\%) patients developed late complications. One patient treated with povo-iodine developed tense ascites. Another patient treated with talc slurry developed tense ascites and hepatic coma at the 3-month follow-up that was treated 


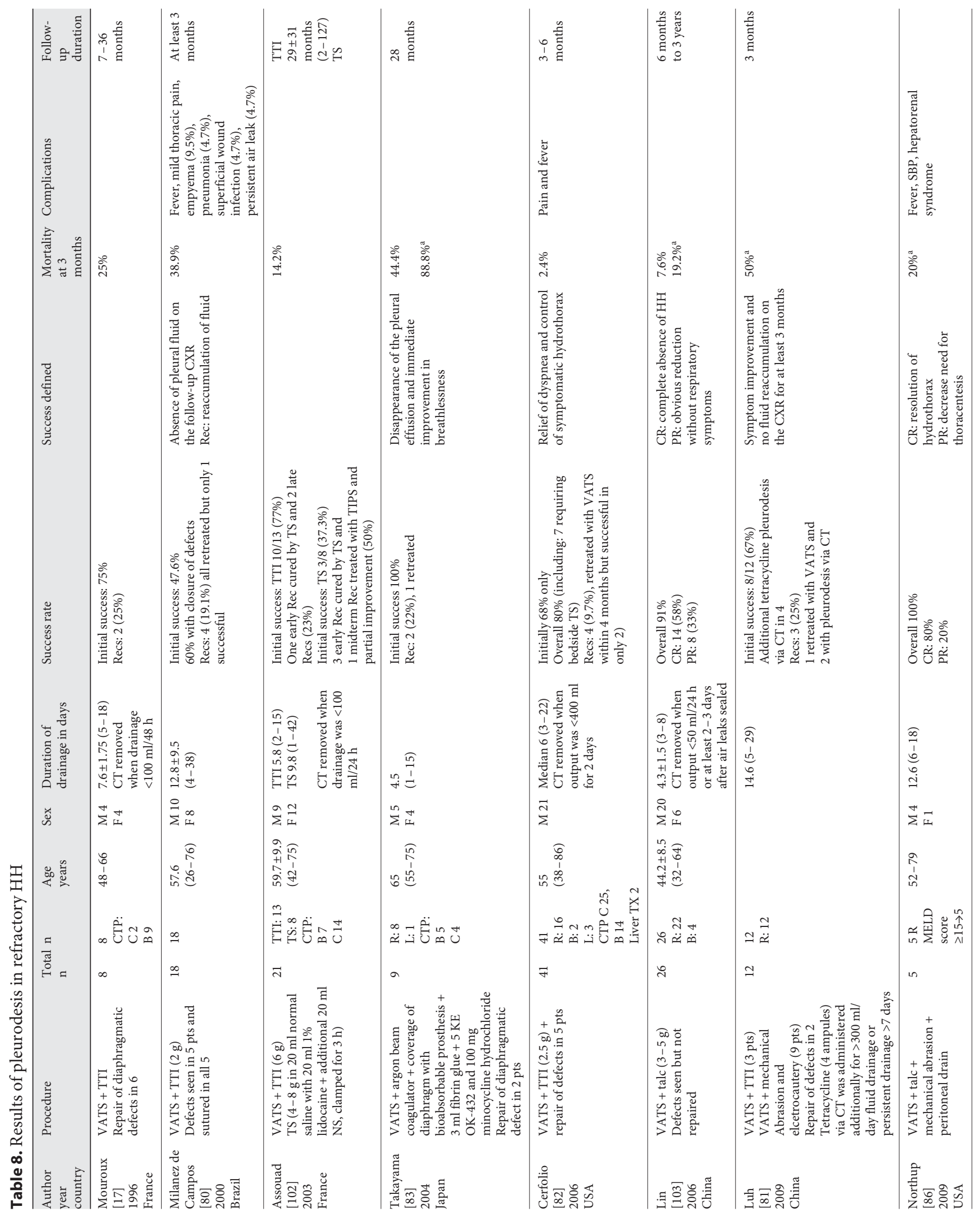




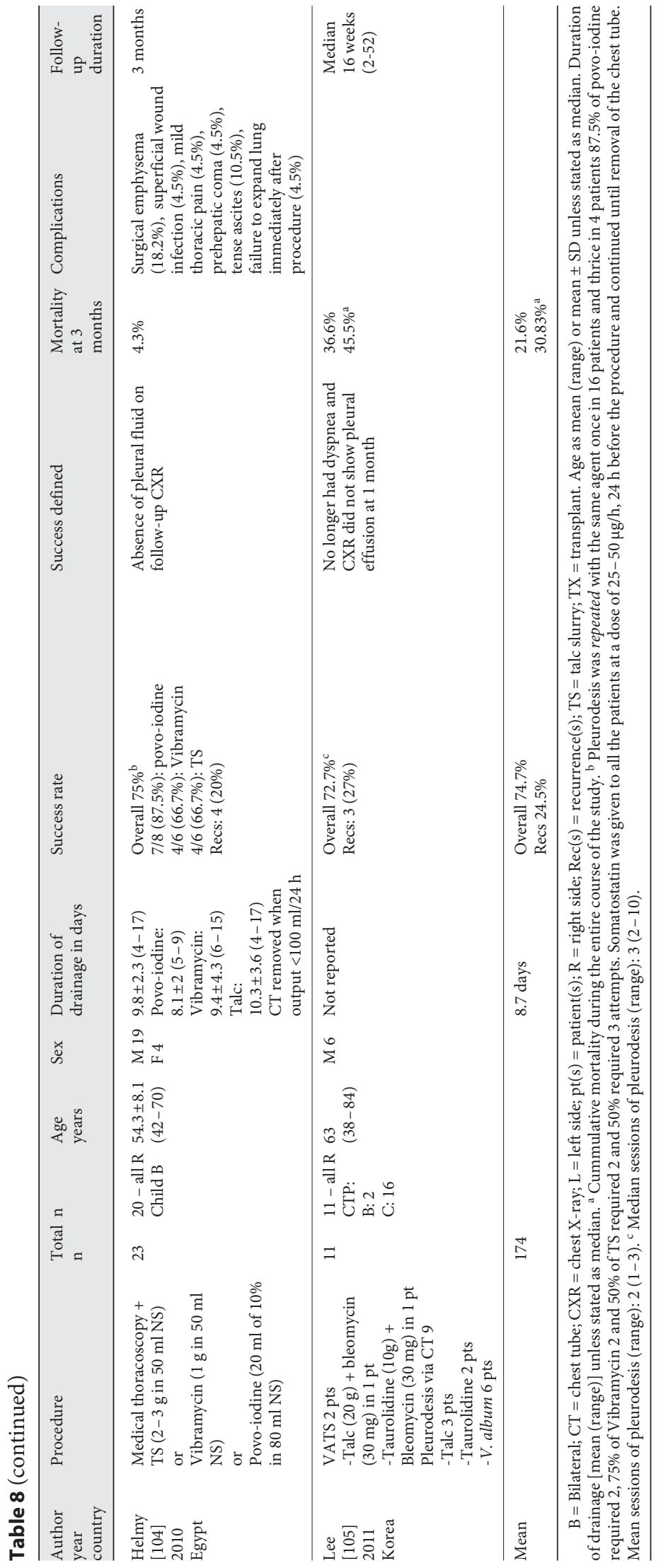

with medical therapy and was also associated with encysted right-sided pleural effusion. There was only 1 single case of mortality (5\%) in a patient treated with talc slurry that occurred 14 days after the procedure due hepatic coma. Only this study compared the success rate of different sclerosing agents. The success rate was $66.7 \%$ with talc slurry, $87.5 \%$ with povo-iodine and $66.7 \%$ with Vibramycin. Since the number of pleurodesis sessions was highest with talc (50\% required two attempts and $50 \%$ required three) and lowest with povo-iodine (87.5\% required two attempts and none required three), povoiodine was shown to be the sclerosing agent with the highest success rate.

\section{VATS and Pleurodesis}

Most of the studies used VATS to achieve pleurodesis. In a retrospective study of 26 patients, pleurodesis was done with VATS using talc with an overall response of $91 \%$ [103]. Only 2 cases failed to respond with a drainage volume of $>600 \mathrm{ml} /$ day. Of the 2 unsuccessful cases, 1 was discharged and lost to follow-up and 1 died of hemorrhage and hepatic encephalopathy 1 month after the procedure. The comparison of VATS using thoracoscopic talc insufflation (TTI) and pleurodesis using talc slurry was done in a study of 21 patients [102]. The initial success rate was $77 \%$ in the VATS group, with 1 early and 2 late recurrences. The talc slurry group had a success rate of $37.3 \%$ and a recurrence rate of $50 \%$. The duration of chest tube drainage was also longer in the talc slurry group (9.8 days) as compared to the VATS group (5.8 days). TIPS was performed in 1 patient after pleurodesis failure but without any marked improvement.

Two studies combined mechanical pleurodesis with talc pleurodesis through VATS. Northup et al. [86] performed VATS with TTI and mechanical pleurodesis in 5 patients followed by intraperitoneal drain with an overall success rate of $100 \%$. The average duration of chest tube drainage was 12.6 days. Diaphragmatic defects could not be visualized in any patient. Intraperitoneal drain was placed after the procedure to prevent reaccumulation of the ascites while pleural inflammation was progressing. All of the 5 patients were either not candidates for TIPS due to poorly controlled encephalopathy and high MELD scores (4 patients had MELD $>15$ ) or had a persistent hydrothorax despite the presence of a mature, functioning TIPS (present in 1 patient with an MELD score of 15). Only 1 patient had intraoperative bleeding in the thoracic cavity with an estimated blood loss of 2 liters, requiring blood transfusion. This patient required complete decortication secondary to trapped lung and empyema, and 
Fig. 2. Proposed algorithm for the management of $\mathrm{HH}$.

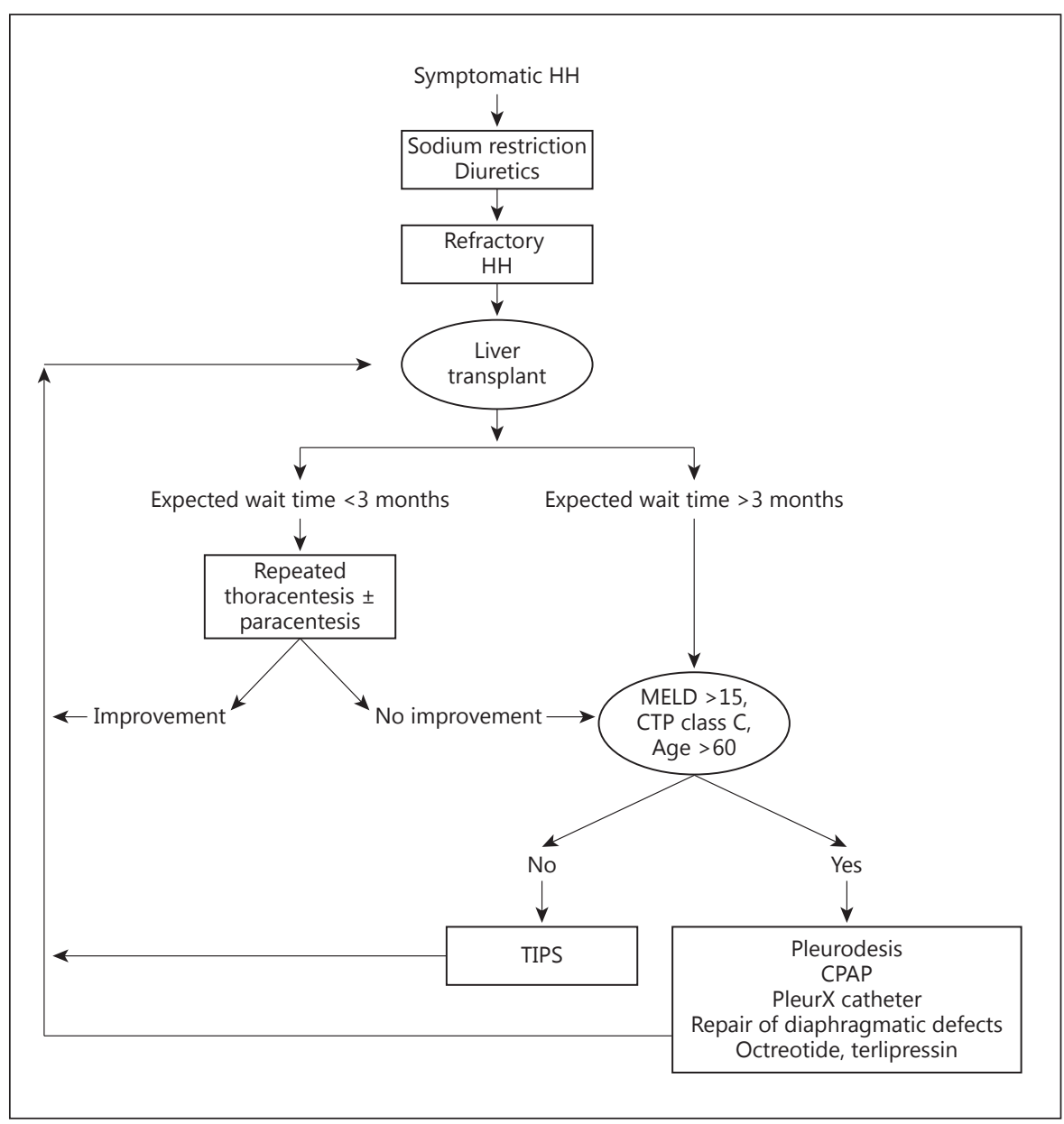

had a preoperative INR of 3.1 and a platelet count of $38,000 / \mu \mathrm{l}$. There was 1 death due to SBP resulting in the hepatorenal syndrome. In another study including a total of 12 patients, 3 underwent VATS with TTI and 9 patients underwent VATS with mechanical abrasion and electrocautery [81]. The initial success rate was $67 \%$. Tetracycline pleurodesis via the chest tube was needed additionally in 4 patients who had fluid drainage $>300 \mathrm{ml} /$ day or persistent drainage for $>7$ days. There were 3 recurrences: 1 was retreated with VATS and 2 with tetracycline pleurodesis via a chest tube.

VATS with Pleurodesis and Repair of Diaphragmatic Defects

VATS also helps in to visualize as well as repair the diaphragmatic defects with fibrin glue or sutures in patients with refractory $\mathrm{HH}$. In a study of 8 patients, diaphragmatic defects were repaired in 6 patients along with VATS and talc pleurodesis [101]. The initial success rate was $75 \%$ with a recurrence of $25 \%$. Out of 2 patients in whom defects could not be visualized even after intraperitoneal dye injection, the duration of drainage was longer and pleural effusion recurred in both. Both of these patients died of hepatocellular insufficiency. In another study of 18 patients by Milanez de Campos et al. [80], diaphragmatic defects were seen in 5 patients and repaired in all 5 . The success rate increased to $60 \%$ from $47.6 \%$ after repair of the diaphragmatic defects. The recurrence rate and duration of chest tube drainage was higher in patients in whom the repair of the diaphragmatic defect could not be performed.

In another study, diaphragmatic defects could only be visualized and repaired in 5 of 41 patients [82]: 25 patients were CTP class C and 14 CTP class B. TIPS was not considered in any patient. All patients underwent VATS and talc pleurodesis, with 7 patients requiring bedside talc slurry later on. In a small study from Tokyo [83], VATS was combined with argon beam coagulation of the 
diaphragm surface followed by covering of the diaphragm with a bioabsorable prosthesis and $3 \mathrm{ml}$ of fibrin glue. The diaphragm surface was then sprinkled with $5 \mathrm{KE}$ of OK-432 and $100 \mathrm{mg}$ of minocycline was instilled into the thoracic cavity. Diaphragmatic defects were repaired in 2 of 9 patients. The initial success rate was $100 \%$ in the study. There were 2 recurrences, 1 was treated with repeat pleurodesis with improvement and 1 was treated conservatively because of end-stage hepatocellular carcinoma.

The most common complications associated with pleurodesis seen in different studies included fever and mild thoracic pain, though empyema, septic shock and hepatic encephalopathy with liver failure have also been reported. Persistent high volume ascitic drainage from the chest tube site causing azotemia and renal failure is another dreaded complication when the chest tube is left for a prolonged period. Mechanical pleurodesis carries a high risk of bleeding especially in patients with advanced liver disease and coagulopathy. The average cumulative mortality rate in all ten studies was $30.83 \%$ and was attributed to hepatocellular insufficiency, hemorrhage due to esophageal varices, hepatic encephalopathy, septic shock and renal failure. The average 30 -day mortality was $21.6 \%$.

Pleurodesis is an effective method for the management of refractory $\mathrm{HH}$. Even though most of the studies have used VATS to achieve pleurodesis with a good overall success rate, it requires the use of general anesthesia which carries substantial risks for patients with end-stage liver disease. In these patients, medical thoracoscopy may be a reasonable option for symptom relief. It is done under local anesthesia with conscious sedation. Somatostatin can be combined with pleurodesis to decrease the portosystemic pressure gradient and reaccumulation of pleural fluid to achieve successful pleurodesis. Paracentesis performed before pleurodesis may also increase the success rate by decreasing ascites and flux of fluid from the peritoneal to the pleural cavity, allowing more time for the pleural spaces to be opposed to each other. The PleurX catheter may also be combined with pleurodesis to avoid and decrease hospitalization in patients, as shown in a study with malignant pleural effusion [106].

\section{Conclusion}

$\mathrm{HH}$ is an uncommon complication of portal hypertension. The pathogenesis involves the migration of fluid from the peritoneal to the pleural cavity through dia- phragmatic defects. Patients may be asymptomatic, and dominating clinical manifestations are liver cirrhosis and portal hypertension; however, pulmonary symptoms like dyspnea and respiratory failure can also be encountered. Diagnosis involves a high index of suspicion in a cirrhotic patient who presents with pleural effusion. Pleural fluid analysis is one of the initial diagnostic steps, with most effusions being transudative. Medical management with salt restriction and diuretics is the first line of therapy. All patients with refractory $\mathrm{HH}$ should be referred for liver transplantation (fig. 2). However, in patients with refractory hydrothorax awaiting transplantation or those who are not candidates for transplantation, management becomes challenging. In these patients, other treatment modalities that focus on reducing ascitic fluid formation, preventing the transfer of ascitic fluid across the diaphragm, drainage and obliteration of the pleural space should be considered. Thoracentesis is the initial modality of choice in refractory hydrothorax patients who fail medical therapy. Paracentesis to drain ascites is usually performed before thoracentesis to prevent the flux of fluid from the peritoneum to the pleural space because of negative intrapleural pressure generated after thoracentesis. When thoracentesis is needed every $2-3$ weeks, patients should be considered for TIPS as a bridge to liver transplant, provided that they are candidates for TIPS. TIPS is associated with poor survival in patients with MELD score $>15$, CTP class C, age $>60$ years and a high pre-TIPS creatinine of $2 \mathrm{mg} / \mathrm{dl}$. In these patients or in patients who do not respond to TIPS, a comprehensive treatment approach combining different treatment modalities should be applied. Obliteration of the pleural space with pleurodesis is a good option for these patients. Repair of the diaphragmatic defects, CPAP and the PleurX catheter can be combined with pleurodesis to increase the success rate. There have not been any comparative studies of the effectiveness of TIPS and pleurodesis in $\mathrm{HH}$ patients. Early diagnosis of $\mathrm{HH}$ is important to establish an appropriate management plan. Both TIPS and pleurodesis with possible VATS-assisted diaphragmatic repair are perhaps the best available therapeutic modalities for bridging a refractory $\mathrm{HH}$ patient to liver transplantation. 


\section{References}

-1 Karen LK, Cardenas A: Hepatic hydrothorax. Semin Respir Crit Care Med 2012;33:3-10.

$>2$ Johnston RF, Loo RV: Hepatic hydrothorax. Ann Intern Med 1964;61:385-401.

-3 Lieberman FL, Peters RL: Cirrhotic hydrothorax: further evidence that an acquired diaphragmatic defect is at fault. Arch Intern Med 1970;125:114-117.

4 Esteve M, Xiol X, Fernadez F, Gonzalez F, Baliellas C: Treatment and outcome of hydrothorax in liver cirrhosis. J Clin Nutr Gastroenterol 1986;1:139-144.

7 Giacobbe A, Facciorusso D, Barbano F, Andriulli A, Frusciante V: Hepatic hydrothorax: diagnosis and management. Clin Nucl Med 1996;21:56-60.

6 Shu-juan J, Song Z, Li-li S, Yi L: Diagnostic and therapeutic value of thoracoscopy for pleural effusions: experience from 628 consecutive cases in China. Chin Med J 2009;122: 1227-1230.

$\checkmark 7$ Chen TA, Lo GH, Lai KH: Risk factors for spontaneous bacterial empyema in cirrhotic patients with hydrothorax. J Chin Med Assoc 2003;66:579-586.

$>8$ Romero S, Candela A, Martin C, Hernandez L, Trigo C, Gil J: Evaluation of different criteria for the separation of pleural transudates from exudates. Chest 1993;104:399-404.

9 Light RW, Macgregor MI, Luchsinger PC, Ball WC Jr: Pleural effusions: the diagnostic separation of transudates and exudates. Ann Intern Med 1972;77:507-513.

10 Castellote J, Xiol X: Hepatic hydrothorax; in Light RW, Lee YCG (eds): Textbook of Pleural Diseases, ed 2. London, Arnold, 2008, pp 402-409.

11 Xiol X, Castellví JM, Guardiola J, et al: Spontaneous bacterial empyema in cirrhotic patients: a prospective study. Hepatology 1996; 23:719-723.

-12 Almdal TP, Skinhøj P: Spontaneous bacterial peritonitis in cirrhosis: incidence, diagnosis, and prognosis. Scand J Gastroenterol 1987; 22:295-300.

13 Albillos A, Cuervas-Mons V, Millán I, et al: Ascitic fluid polymorphonuclear cell count and serum to ascites albumin gradient in the diagnosis of bacterial peritonitis. Gastroenterology 1990;98:134-140.

$\checkmark 14$ Kirschner PA: Porous diaphragm syndromes. Chest Surg Clinic N Am 1998;8:449-472.

-15 Higgins G, Kelsall AR, O’Brien JRP, Stewart AM, Witts LJ: Ascites in chronic disease of the liver. QJ Med 1947;16:263-274.

$\checkmark 16$ Durmont AE, Mulholland JH: Flow rate and composition of thoracic duct lymph in patients with cirrhosis. N Engl J Med 1960;263: 471-474.

-17 Mouroux J, Perrin C, Venissac N, Blaive B, Richelme H: Management of pleural effusion of cirrhotic origin. Chest 1996;109:10931096.
18 Chen A, Ho YS, Tu YC, Tang HS, Cheng TC: Diaphragmatic defect as a cause of massive hydrothorax in cirrhosis of liver. J Clin Gastroenterol 1988;10:663-666.

19 Zenda T, Miyamoto S, Murata S, Mabuchi H: Detection of diaphragmatic defect as the cause of severe hepatic hydrothorax with magnetic resonance imaging. Am J Gastroenterol 1998;93:2288-2289.

20 Lieberman FL, Hidemura R, Peters RL, Reynolds TB: Pathogenesis and treatment of hydrothorax complicating cirrhosis with ascites. Ann Intern Med 1966;64:341-351.

21 Alberts WM, Salem AJ, Solomon DA, Boyce G: Hepatic hydrothorax. Cause and management. Arch Intern Med 1991;151:23832388.

22 Huang PM, Chang YL, Yang CY, Lee YC: The morphology of diaphragmatic defects in hepatic hydrothorax: thoracoscopic finding. J Thorac Cardiovasc Surg 2005;130:141-145.

23 Benet A, Vidal F, Toda R, Siurana R, De Virgala CM, Richart C: Diagnosis of hepatic hydrothorax in the absence of ascites by intraperitoneal injection of $99 \mathrm{~m}$-Tc-fluor colloid. Postgrad Med J 1992;68:153.

24 Serena A, Aliaga L, Richter JA, Calderon R, Sanchez L, Charvet MA: Scintigraphic demonstration of a diaphragmatic defect as the cause of massive hydrothorax in cirrhosis. Eur J Nucl Med 1985;11:46-48.

25 Fathy O, Zeid MA, Abdallah T, et al: Laparoscopic cholecystectomy: a report on 2000 cases. Hepatogastroenterology 2003;50:967-971.

26 Xiol X, Castellote J, Baliellas C, Ariza J, Gimenez A, Guardiola J, Casais L: Spontaneous bacterial empyema in cirrhotic patients: analysis of eleven cases. Hepatology 1990;11: 365-370.

27 Eid AA, Keddissi JI, Kinasewitz GT: Hypoalbuminemia as a cause of pleural effusions. Chest 1999;115:1066-1069.

28 Keddissi JI, Eid AA, Janbey EM, et al: Incidence and outcome of hydrothorax in patients with chronic liver disease. Chest 2002; 122:94S.

29 Nolop KB: Massive hydrothorax complicating occult cirrhosis. South Med J 1985;78: 214-215.

$>30$ Pop CM, Gherasim RM, Dumitrascu DL: Hydrothorax without ascites in liver cirrhosis. Rom J Gastroenterol 2003;12:315-317.

31 Rubinstein D, McInnes IE, Dudley FJ: Hepatic hydrothorax in the absence of clinical ascites: diagnosis and management. Gastroenterology 1985;88:188-191.

32 Kirsch CM, Chui DW, Yenokida GG, Jensen WA, Bascom PB: Case report: hepatic hydrothorax without ascites. Am J Med Sci 1991; 302:103-106.
33 Siegerstetter V, Deibert P, Ochs A, Olschewski M, Blum HE, Rössle M: Treatment of refractory hepatic hydrothorax with transjugular intrahepatic portosystemic shunt: longterm results in 40 patients. Eur J Gastroenterol Hepatol 2001;13:529-534.

34 Gurung P, Goldbatt M, Huggins J, Doelkin P, Nietert P, Sahn S: Pleural fluid analysis and radiographic, sonographic, and echocardiographic characteristics of hepatic hydrothorax. Chest 2011;140:448-453.

35 Castellote J, Gornals J, Lopez C, Xiol X: Acute tension hydrothorax: a life-threatening complication of cirrhosis. J Clin Gastroenterol 2002;34:588-589.

36 Kaplan LM, Epstein SK, Schwartz SL, Cao QL, Pandian NG: Clinical, echocardiographic and hemodynamic evidence of cardiac tamponade caused by large pleural effusions. Am J Respir Crit Care Med 1995;151:904-908.

37 Xiol X, Castellote J, Cortes-Beut R, Delgado M, Guardiola J, Sesé E: Usefulness and complications of thoracentesis in cirrhotic patients. Am J Med 2001;111:67-69.

38 Mirouze D, Juttner HU, Reynolds TB: Left pleural effusion in patients with chronic liver disease and ascites: prospective study of 22 cases. Dig Dis Sci 1981;26:984-988.

39 Beilsa S, Porcel JM, Castellote J, Mas E, Esquerda A, Light RW: Solving the Light's criteria misclassification rate of cardiac and hepatic transudates. Respirology 2012;17:721-726.

40 Sesé E, Xiol X, Castellote J, Rodríguez-Fariñas E, Tremosa G: Low complement levels and opsonic activity in hepatic hydrothorax: its relationship with spontaneous bacterial empyema. J Clin Gastroenterol 2003;36:75-77.

41 Ajmi S, Hassine H, Guezguez M, et al: Isotopic exploration of hepatic hydrothorax: ten cases. Gastroenterol Clin Biol 2004;28:462466.

-42 Bhattacharya A, Mittal BR, Biswas T, et al: Radioisotope scintigraphy in the diagnosis of hepatic hydrothorax. J Gastroenterol Hepatol 2001;16:317-321.

43 Umino J, Tanaka E, Ichijoh T, et al: Hepatic hydrothorax in the absence of ascites diagnosed by intraperitoneal spraying of indocyanine green. Intern Med 2004;43:283-288.

44 Tamana M, Hashimoto T, Kojima K, Maeda C, Hiraishi H: Diagnosis of hepatic hydrothorax using contrast-enhanced ultrasonography with intraperitoneal injection of Sonazoid. J Gastroenterol Hepatol 2010;25:383-386.

45 Zenda T, Miyamoto S, Murata S, Mabuchi H: Detection of diaphragmatic defect as the cause of severe hepatic hydrothorax with magnetic resonance imaging. Am J Gastroenterol 1998;93:2288-2289.

46 Lau KK, Arkles B, McKenzie A: A case of hepatic hydrothorax due to a large diaphragmatic defect. Australas Radiol 1992;36:160162 . 
47 Pozzi M, Carugo S, Boari G, et al: Evidence of functional and structural cardiac abnormalities in cirrhotic patients with and without ascites. Hepatology 1997;26:1131-1137.

-48 Møller S, Henriksen JH: Cardiovascular complications of cirrhosis. Gut 2008;57:268-278.

49 Cardenas A, Kelleher T, Chopra S: Review article: hepatic hydrothorax. Aliment Pharmacol Ther 2004;20:271-279.

-50 Garcia N Jr, Mihas AA: Hepatic hydrothorax. Pathophysiology, diagnosis, and management. J Clin Gastroenterol 2004;38:52-58.

51 Lucey MR, Brown KA, Everson GT, et al: Minimal criteria for placement of adults on the liver transplant waiting list: a report of a national conference organized by the American Society of Transplant Physicians and the American Association for the Study of Liver Diseases. Liver Transpl Surg 1997;3:628-637.

- 52 Everhart JE, Lombardero M, Detre KM, Zetterman RK, Wiesner RH, Lake JR, Hoofnagle $\mathrm{JH}$ : Increased waiting time for liver transplantation results in higher mortality. Transplantation 1997;64:1300-1306.

-53 Broelsch CE, Testa G, Alexandrou A, Malagó M: Living related liver transplantation: medical and social aspects of a controversial therapy. Gut 2002;50:143-145.

54 Liu WL, Kuo PH, Huang PM, Yang PC: Impact of therapeutic interventions on survival of patients with hepatic hydrothorax. J Formos Med Assoc 2010;109:582-588.

55 Al-sharif H, Sharma S: Hepatic hydrothorax - how would you manage it? Can Respir J 2005; 12:440-442.

-56 Runyon BA, Practice Guidelines Committee, American Association for the Study of Liver Diseases (AASLD): Management of adult patients with ascites due to cirrhosis. Hepatology 2004;39:841-856.

57 Moore KP, Wong F, Gines P, et al: The management of ascites in cirrhosis: report on the consensus conference of the International Ascites Club. Hepatology 2003;38:258-266.

58 Garcia-Tsao G: Current management of the complications of cirrhosis and portal hypertension: variceal hemorrhage, ascites, and spontaneous bacterial peritonitis. Gastroenterology 2001;120:726-748.

-59 Ibrisim D, Cakaloglu Y, Akyuz F, et al: Treatment of hepatic hydrothorax with terlipressin in a cirrhotic patient. Scand J Gastroenterol 2006; $41: 862-865$.

- 60 Barreales M, Sáenz-López S, Igarzabal A, et al: Refractory hepatic hydrothorax: successful treatment with octreotide. Rev Esp Enferm Dig 2005;97:830-835.

61 Kalambokis G, Fotopoulos A, Economou M, Tsianos EV: Beneficial haemodynamic and renal sodium handling effects of combined midodrine and octreotide treatment in a cirrhotic patient with large hepatic hydrothorax and mild ascites. Nephrol Dial Transplant 2005;20:2583.
62 Kalambokis G, Economou M, Fotopoulos A, et al: The effects of chronic treatment with octreotide versus octreotide plus midodrine on systemic hemodynamics and renal hemodynamics and function in nonazotemic cirrhotic patients with ascites. Am J Gastroenterol 2005; 100:879-885.

63 Conklin LD, Estrera AL, Weiner MA, Reardon PR, Reardon MJ: Transjugular intrahepatic portosystemic shunt for recurrent hepatic hydrothorax. Ann Thorac Surg 2000;69: 609-611.

64 Strauss RM, Martin LG, Kaufman SL, et al: Transjugular intrahepatic portal systemic shunt for the management of symptomatic cirrhotic hydrothorax. Am J Gastroenterol 1994;92:1520-1522.

65 Gordon FD, Anastopoulos HT, Crenshaw W, et al: The successful treatment of symptomatic, refractory hepatic hydrothorax with transjugular intrahepatic portosystemic shunt. Hepatology 1997;25:1366-1369.

- 66 Jeffries MA, Kazanjian S, Wilson M, et al: Transjugular intrahepatic portosystemic shunts and liver transplantation in patients with refractory hepatic hydrothorax. Liver Transpl Surg 1998;4:416-423.

67 Chalasani N, Clark WS, Martin LG, et al: Determinants of mortality in patients with advanced cirrhosis after transjugular intrahepatic portosytemic shunting. Gastroenterology 2000;118:138-144.

68 Spencer EB, Cohen DT, Darey MD: Safety and efficacy of transjugular intrahepatic portosystemic shunt creation for the treatment of hepatic hydrothorax. J Vasc Interv Radiol 2002;13:385-390.

69 Wilputte JY, Goffette P, Zech F, et al: The outcome after transjugular intrahepatic portosystemic shunts (TIPS) for hepatic hydrothorax is closely related to liver dysfunction: a long-term study in 28 patients. Acta Gastroenterol Belg 2007;70:6-10.

-70 Dhanasekaran R, West JK, Gonzales PC, et al: Transjugular intrahepatic portosystemic shunt for symptomatic refractory hepatic hydrothorax in patients with cirrhosis. Am J Gastroenterol 2010;105:635-641.

71 Bureau C, Pagan JCG, Layrargues GP, et al: Patency of stents covered with polytetrafluoroethylene in patients treated by transjugular intrahepatic portosystemic shunts: long-term results of a randomized multicentre study. Liver Int 2007;27:742-747.

72 Boyer TD, Haskal ZJ: The role of transjugular intrahepatic portosystemic shunt (TIPS) in the management of portal hypertension: update 2009. Hepatology 2010;51:1-16.

73 Xiol X, Tremosa G, Castellote J, et al: Liver transplantation in patients with hepatic hydrothorax. Transpl Int 2005;18:672-675.

74 Sersté T, Moreno C, Francoz C, et al: The impact of preoperative hepatic hydrothorax on the outcome of adult liver transplantation. Eur J Gastroenterol Hepatol 2010;22:207212.
75 Angueira CE, Kadakia SC: Effects of largevolume paracentesis on pulmonary function in patients with tense cirrhotic ascites. Hepatology 1994;20:825-828.

76 Levesque E, Hoti E, Jiabin J, et al: Respiratory impact of paracentesis in cirrhotic patients with acute lung injury. J Crit Care 2011;26: 257-261.

77 Wong F: Management of ascites in cirrhosis. J Gastroenterol Hepatol 2012;27:11-20.

78 Ibi T, Koizumi K, Hirata T, et al: Diaphragmatic repair of two cases of hepatic hydrothorax using video-assisted thoracoscopic surgery. Gen Thorac Cardiovasc Surg 2008;56:229-232.

79 Huang PM, Kuo SW, Lee JM: Thoracoscopic diaphragmatic repair for refractory hepatic hydrothorax: application of pleural flap and mesh onlay reinforcement. Thorac Cardiovasc Surg 2006;54:47-50.

80 Milanez de Campos JR, Filho LO, de Campos Werebe E, et al: Thoracoscopy and talc poudrage in the management of hepatic hydrothorax. Chest 2000;118:13-17.

81 Luh SP, Chen CY: Video-assisted thoracoscopic surgery (VATS) for the treatment of hepatic hydrothorax: report of twelve cases. J Zhejiang Univ Sci B 2009 10:547-551.

82 Cerfolio RJ, Bryant AS: Efficacy of video-assisted thoracoscopic surgery with talc pleurodesis for porous diaphragm syndrome in patients with refractory hepatic hydrothorax. Ann Thorac Surg 2006;82:457-459.

83 Takayama T, Kurokawa Y, Kaiwa Y, et al: A new technique of thoracoscopic pleurodesis for refractory hepatic hydrothorax. Surg Endosc 2004;18:140-143.

84 Ferrante D, Arguedas MR, Cerfolio RJ, Collins BG, van Leeuwen DJ: Video-assisted thoracoscopic surgery with talc pleurodesis in the management of symptomatic hepatic hydrothorax. Am J Gastroenterol 2002;97:3172-3175.

85 Takahashi K, Chin K, Sumi K, Nakamura T, Matsumoto H, Niimi A, et al: Resistant hepatic hydrothorax: a successful case with treatment by nCPAP. Respir Med 2005;99: 262-264.

86 Northup PG, Harmon RC, Pruett TL, Schenk WG III, Daniel TM, Berg CL: Mechanical pleurodesis aided by peritoneal drainage: procedure for hepatic hydrothorax. Ann Thorac Surg 2009;87:245-250.

87 Feller-Kopman D, Berkowitz D, Boiselle P, Ernst A: Large-volume thoracentesis and the risk of reexpansion pulmonary edema. Ann Thorac Surg 2007;84:1656-1661.

88 Feller-Kopman D, Walkey A, Berkowit D, Ernst A: The relationship of pleural pressure to symptom development during therapeutic thoracentesis. Chest 2006;129:1556-1560.

89 McVay PA, Toy PT: Lack of increased bleeding after liver biopsy in patients with mild hemostatic abnormalities. Am J Clin Pathol 1990;94:747-753.

90 Borchardt J, Smirnov A, Metchnik L, Malnick S: Lesson of the week: treating hepatic hydrothorax. BMJ 2003;326:751-752. 
-91 Orman ES, Lok AS: Outcomes of patients with chest tube insertion for hepatic hydrothorax. Hepatol Int 2009;3:582-586.

-92 Liu LU, Haddadin HA, Bodian CA, et al: Outcome analysis of cirrhotic patients undergoing chest tube placement. Chest 2004;126: 142-148.

93 Tremblay A, Michaud G: Single-center experience with 250 tunneled pleural catheter insertions for malignant pleural effusion. Chest 2006;129:362-368.

94 Mercky P, Sakr L, Heyries L, et al: Use of a tunneled pleural catheter for the management of refractory hepatic hydrothorax: a new therapeutic option. Respiration 2010;80:348-352.

$\checkmark 95$ Chalhoub M, Harris K, Castellano M, Maroun R, Bourjeily G: The use of the PleurX catheter in the management of non-malignant pleural effusions. Chron Respir Dis 2011;8:185-191.

96 Kilburn JP, Hutchings J, Misselhorn D, Chen AC: Use of indwelling tunneled pleural catheters for the management of hepatic hydrothorax. Chest 2010;138:418A.
97 Herlihy JP, Loyalka P, Gnananandh J, et al: PleurX catheter for the management of refractory pleural effusions in congestive heart failure. Tex Heart Inst J 2009;36:38-43.

$>98$ Hadsaitong D, Suttithawil W: Pleurovenous shunt in treating refractory nonmalignant hepatic hydrothorax: a case report. Respir Med 2005;99:1603-1605.

-99 Bayram AS, Köprücüoğlu M, Aygün M, Gebitekin C: Pleurovenous shunt for treating refractory benign pleural effusion. Eur J Cardiothorac Surg 2008;33:942-943.

100 Artemiou O, Marta GM, Klepetko W, Wolner E, Muller MR: Pleurovenous shunting in the treatment of nonmalignant pleural effusion. Ann Thorac Surg 2003;76:231233.

101 Mouroux J, Perrin C, Vennisac N, Blaive B, Richelme H: Management of pleural effusion of cirrhotic origin. Chest 1996;109: 1093-1096.
102 Assouad J, Barthes Fle P, Shaker W, Souilamas R, Riquet M: Recurrent pleural effusion complicating liver cirrhosis. Ann Thorac Surg 2003;75:986-989.

03 Lin DJ, Zhang M, Gao GX, Li B, Wang MF, Zhu L, Xue LF: Thoracoscopy for diagnosis and management of refractory hepatic hydrothorax. Chin Med J (Engl) 2006;119: 430-434.

104 Helmy N, Akl Y, Kaddah SC, et al: A case series: Egyptian experience in using chemical pleurodesis as an alternative management in refractory hepatic hydrothorax. Arch Med Sci 2010;6:336-342.

105 Lee WJ, Kim HJ, Park JH, et al: Chemical pleurodesis for the management of refractory hepatic hydrothorax in patients with decompensated liver cirrhosis. Korean J Hepatol 2011;17:292-298.

106 Reddy C, Ernest A, Lamb C, Feller-Kopman $D$ : Rapid pleurodesis for malignant pleural effusions: a pilot study. Chest 2011;139: 1419-1423. 